\title{
THE ANALYSIS OF FINANCIAL RESERVES FOR THE STATE SOCIAL INSURANCE
}

\author{
Anatoliy SYDORCHUK ${ }^{1}$ \\ Ternopil National Economic University, Ukraine
}

\begin{abstract}
The purpose of the paper is research of practice of making financial reserves of the state social insurance in Ukraine and determining their optimal size. The method of study allows finding how the financial reserves ensuring sustainability of the state social insurance over three years $(2014,2015,2016)$. Methodology. The results of the study were obtained after analysing the indicators of the budget of state social insurance funds $(2014,2015$, 2016). In the course of research, an analysis and synthesis as methods of theoretical knowledge of phenomena are used. Comparisons and measurements are used as empirical methods for the conducted research. Results of the research showed the lack of uniform methodological principles for the formation of financial reserves of state social insurance, which is confirmed by their various volumes, and the absence of the mandatory creation condition of them. Extrapolating the provisions of Article 14-3 of the Budget Code of Ukraine, we propose that the amount of cash in circulation should not exceed $2 \%$ of the budget expenditures of the state social funds, that is, to provide a seven-day need for financing the insurance payments. At the same time, the condition of keeping the amount of cash on hand at the end of the period (year) should become mandatory. Practical implications. For conducting research and substantiation of relevant conclusions, the indicators of budgets of the state social insurance funds of Ukraine for three years are analysed $(2014,2015,2016)$. Value/originality. A step that will balance the financial resources of state social insurance is the need to introduce uniform requirements for the formation of financial reserves of state social insurance funds. The proposed measures will enable to make more manageable the system of the state social insurance funds in Ukraine.
\end{abstract}

Key words: financial reserves, state social insurance, optimal size of financial reserves, sustainability of state social insurance.

JEL Classification: H55, 113

\section{Introduction}

One of the elements of the financial resources of the state social insurance is financial reserves, which represent money that is deliberately withdrawn from the turnover in state social insurance funds and is intended for the use in unpredictable processes of social reproduction (Zlepko, Kramarchuk, 2007). Also, the financial reserves are the ways and forms of creation and use of funds of financial resources to finance measures to localize the effects of unforeseen circumstances and support the welfare of citizens (Vasylyk, 2000). Therefore, the functional purpose of social insurance reserves, in our opinion, is to ensure the stability of the provision of public services for those persons who are directly involved in this area. Financial reserves of social insurance are determined by us as a part of the state social insurance financial resources, whose main purpose is to ensure the sustainability of the system of state social insurance. Finding the answers to questions "Have the financial reserves of the state social insurance

Corresponding author:

${ }^{1}$ Department of Finance named after S.I. Yurii, Ternopil National Economic University.

E-mail: a.sydorchuk@tneu.edu.ua done their aim in Ukraine?" determines the relevance of the article of the study.

\section{The composition of the financial reserves of the state social insurance}

The practice of functioning of the state social funds shows the creation of the financial reserves in two forms: the current cash reserve and the balance of cash at the beginning of the budget period. On this basis, the financial reserves of the state social insurance are considered by us as currently (the current cash reserve, Crv) and perspectively (the balance of cash at the beginning of the budget period, Prv) (Fig. 1).

The Crv is the current cash at the beginning of the period to cover temporary cash disruptions to finance insurance payments, social services of the current month. Extrapolating the provisions of Article 14-3 of the Budget Code of Ukraine (The Budget Code of Ukraine, 2010), we consider Crv is a part of the budget of the state social insurance fund, which is formed at 


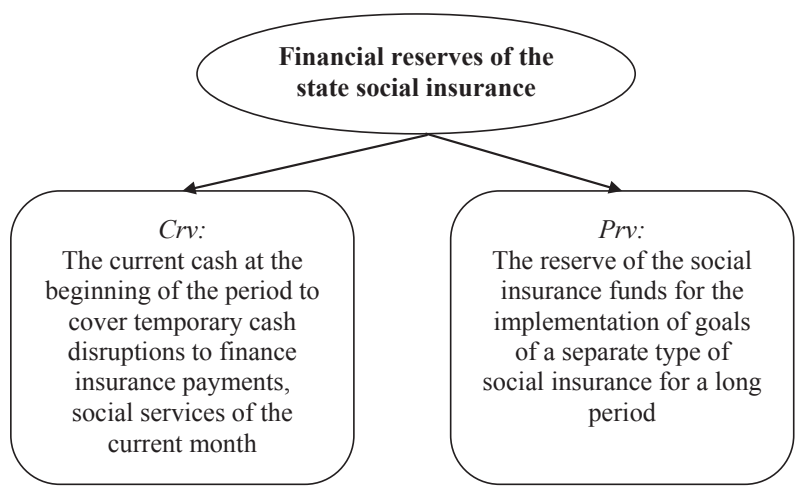

Fig. 1. Composition of the financial reserves of the state social insurance

the beginning of the period to cover temporary cash disruptions for the financing of insurance payments, social services of the current month.

The perspective financial reserves (Prv) of the state social insurance funds include a reserve of funds to ensure the implementation of goals of a separate type of the state social insurance for a long period. In particular, they should include the difference between the remainder of the budget of a separate state social fund and the current cash at the end of the period. It is a free remaining balance that is not subject to withdrawal and is used to carry out expenditures in accordance with perspective decisions of the respective board of the state social fund.

Unlike other types of social insurance, formatting Crv and Prv of the State Social Insurance Fund for Temporary Incapacity and the Compulsory State Social Insurance Fund of Ukraine for Unemployment in 2002-2007 was envisaged by law.

The dynamics of indicators of the financial reserves of the social insurance for the unemployment is presented in Table 1.

Listed in Table 1 data about the financial reserves of social insurance for unemployment in Ukraine indicate:

A) Absence of the financial reserves in 2014;

B) The creation of the financial reserves in 2015 and
2016 at $1 \%$ of the Compulsory State Social Insurance Fund of Ukraine for Unemployment total expenditures to cover the 4-day expenditure need;

C) Absence of perspective reserves in 2014-2016.

The lack of the financial reserves in 2014 is due to the beginning of hostilities in Ukraine. The indicator Crv for the social insurance for unemployment, expressed in days, showed a deviation of its volume from the norm. This is especially noticeable during 2015-2016, when it provided funding for this type of the state social insurance for 4 days, instead of 7 days. By doing so, it reached its critical minimum level. The absence of Prv in 2014-2016 demonstrates the absence of long-term state policy in the development of this type of the social insurance.

The dynamics of indicators of the financial reserves of the social insurance for temporary incapacity is presented in Table 2.

Listed in Table 2 data about the financial reserves of social insurance for unemployment in Ukraine indicate:

A) The indicator Crv in 2015 has decreased by almost twice as compared to 2014;

B) In 2015, the balance of cash of the State Social Insurance Fund for Temporary Incapacity was formed at the end of the reporting year in the amount of 1759.8 million UAH, which is $25.39 \%$ of the Fund's total expenditures. However, according to data, the Fund's expenditures were financed only by $77.8 \%$, or the share of underfunding was $22.2 \%$. Thus, the real balance of the cash at the end of the reporting year was $3.19 \%$. It is $3.19 \%$ that is the real value of the Crv in 2015;

C) Absence of perspective reserves in 2014-2015.

The decrease of the financial reserves in 2015 is due to the beginning of hostilities in Ukraine. The indicator Crv for the social insurance for temporary incapacity, expressed in days, showed its volume in the norm. This is especially noticeable in 2014, when it provided funding for this type of the state social insurance for 22 days, instead of 7 days. By doing so, it reached its critical maximum level.

Table 1

The indicators of financial reserves of the social insurance for unemployment

\begin{tabular}{|c|c|c|c|}
\hline Indicators & 2014 & 2015 & 2016 \\
\hline Prv, thousand UAH & - & - & - \\
\hline Crv, thousand UAH & - & 82,8 & 91 \\
\hline The total financial reserves, thousand UAH & - & 82,8 & 91 \\
\hline $\begin{array}{l}\text { The total expenditures of the Compulsory State Social Insurance Fund of Ukraine } \\
\text { for Unemployment, thousand UAH }\end{array}$ & 6883,7 & 8269,7 & 8573,5 \\
\hline $\begin{array}{l}\text { Specific weight of Prv in the total expenditures of the Compulsory State Social } \\
\text { Insurance Fund of Ukraine for Unemployment, } \%\end{array}$ & - & - & - \\
\hline $\begin{array}{l}\text { Specific weight of Crv in the total expenditures of the Compulsory State Social } \\
\text { Insurance Fund of Ukraine for Unemployment, \% }\end{array}$ & - & 1 & 1,06 \\
\hline $\begin{array}{l}\text { Specific weight of the total financial reserves in the total expenditures of the } \\
\text { Compulsory State Social Insurance Fund of Ukraine for Unemployment, \% }\end{array}$ & - & 1 & 1,06 \\
\hline Prv, day & - & - & - \\
\hline Crv, day & - & 4 & 4 \\
\hline
\end{tabular}


Table 2

The indicators of financial reserves of the social insurance for temporary incapacity

\begin{tabular}{|c|c|c|}
\hline Indicators & 2014 & 2015 \\
\hline Prv, thousand UAH & - & - \\
\hline Crv, thousand UAH & 607,9 & 1759,8 \\
\hline The total financial reserves, thousand UAH & 607,9 & 1759,8 \\
\hline $\begin{array}{l}\text { The total expenditures of the State Social } \\
\text { Insurance Fund for Temporary Incapacity, } \\
\text { thousand UAH }\end{array}$ & 10180,8 & 6930,4 \\
\hline $\begin{array}{l}\text { Specific weight of Prv in the total } \\
\text { expenditures of the State Social Insurance } \\
\text { Fund for Temporary Incapacity, \% }\end{array}$ & - & - \\
\hline $\begin{array}{l}\text { Specific weight of Crv in the total } \\
\text { expenditures of the State Social Insurance } \\
\text { Fund for Temporary Incapacity, \% }\end{array}$ & 5,97 & $\begin{array}{c}25,39 \\
(3,19)\end{array}$ \\
\hline $\begin{array}{l}\text { Specific weight of the total financial reserves } \\
\text { in the total expenditures of the State Social } \\
\text { Insurance Fund for Temporary Incapacity, \% }\end{array}$ & - & $\begin{array}{c}25,39 \\
(3,19)\end{array}$ \\
\hline Prv, day & - & - \\
\hline Crv, day & 22 & 11 \\
\hline
\end{tabular}

Also, the absence of Prv in 2014-2015 demonstrates the absence of long-term state policy in the development of this type of the social insurance.

The dynamics of indicators of the financial reserves of the state social insurance against accidents at work and occupational diseases is presented in Table 3.

Table 3

The indicators of financial reserves of the social insurance against accidents at work and occupational diseases

\begin{tabular}{|l|c|c|}
\hline \multicolumn{1}{|c|}{ Indicators } & 2014 & 2015 \\
\hline Prv, thousand UAH & - & - \\
\hline Crv, thousand UAH & 60,2 & 590,4 \\
\hline The total financial reserves, thousand UAH & 60,2 & 590,4 \\
\hline $\begin{array}{l}\text { The total expenditures of the State Social } \\
\text { Insurance Fund against Accidents at Work } \\
\text { and Occupational Diseases, thousand UAH }\end{array}$ & 7758,6 & 7091,8 \\
\hline $\begin{array}{l}\text { Specific weight of Prv in the total } \\
\text { expenditures of the State Social Insurance } \\
\text { Fund against Accidents at Work and } \\
\text { Occupational Diseases, \% }\end{array}$ & - & - \\
\hline $\begin{array}{l}\text { Specific weight of Crv in the total } \\
\text { expenditures of the State Social Insurance } \\
\text { Fund against Accidents at Work and } \\
\text { Occupational Diseases, \% }\end{array}$ & 0,78 & 8,33 \\
\hline $\begin{array}{l}\text { Specific weight of the total financial reserves } \\
\text { in the total expenditures of the State the } \\
\text { Social Insurance Fund against Accidents at } \\
\text { Work and Occupational Diseases, \% }\end{array}$ & 0,78 & 8,33 \\
\hline Prv, day & - & - \\
\hline Crv, day & 3 & 1 \\
\hline
\end{tabular}

Listed in Table 3 data about the financial reserves of social insurance against accidents at work and occupational diseases indicate:
A) The indicator Crv in 2015 has decreased by in six times as compared to 2014;

B) In 2015, the balance of the cash of the State Social Insurance Fund against Accidents at Work and Occupational Diseases was formed at the end of the reporting year in the amount of 0.5904 million UAH, which is $8.33 \%$ of the Fund's total expenditures. However, according to data, the Fund's expenditures were financed only by $91.8 \%$, or the share of underfunding was $8.2 \%$. Thus, the real balance of the cash at the end of the reporting year was $0.13 \%$. It is $0.13 \%$ that is the real value of the Crv in 2015;

C) Absence of perspective reserves in 2014-2015.

As other types of the state social insurance, the decrease of the financial reserves in 2015 is due to the beginning of hostilities in Ukraine. The indicator Crv for the social insurance against accidents at work and occupational diseases, expressed in days, showed a deviation of its volume from the norm. This is especially noticeable in 2015, when it provided funding for this type of the state social insurance for 1 day, instead of 7 days. By doing so, it reached its critical minimum level.

Also, the absence of Prv in 2014-2015 demonstrates the absence of long-term state policy in the development of this type of the social insurance.

The State Social Insurance Fund for Temporary Incapacity and the State Social Insurance Fund against Accidents at Work and Occupational Diseases are united in one - the State Social Insurance Fund of Ukraine. For the first time, the Social Insurance Fund of Ukraine approved its budget in 2016.

The dynamics of indicators of the financial reserves of the state social insurance (that including the social insurance for temporary incapacity and the social insurance against accidents at work and occupational diseases) is presented in Table 4.

\section{Table 4}

The indicators of financial reserves of the state social insurance

\begin{tabular}{|l|c|}
\hline \multicolumn{1}{|c|}{ Indicators } & 2016 \\
\hline Prv, thousand UAH & - \\
\hline Crv, thousand UAH & 218,9 \\
\hline The total financial reserves, thousand UAH & 218,9 \\
\hline $\begin{array}{l}\text { The total expenditures of the State Social Insurance } \\
\text { Fund, thousand UAH }\end{array}$ & 16886,8 \\
\hline $\begin{array}{l}\text { Specific weight of Prv in the total expenditures } \\
\text { of the State Social Insurance Fund, \% }\end{array}$ & - \\
\hline $\begin{array}{l}\text { Specific weight of Crv in the total expenditures } \\
\text { of the State Social Insurance Fund, \% }\end{array}$ & 1,3 \\
\hline $\begin{array}{l}\text { Specific weight of the total financial reserves in the total } \\
\text { expenditures of the State Social Insurance Fund against } \\
\text { Accidents at Work and Occupational Diseases, \% }\end{array}$ & 1,3 \\
\hline Prv, day & 5 \\
\hline Crv, day & 5 \\
\hline
\end{tabular}

Listed in Table 4 data about the financial reserves of social insurance indicate: 
A) The creation of financial reserves in 2016 at $1.3 \%$ of the State Social Insurance Fund's total expenditures to cover the 5-day expenditure need;

B) Absence of perspective reserves in 2016.

The indicator Crv for the social insurance of Ukraine, expressed in days, showed a small deviation of its volume from the norm. It provided funding for this type of the state social insurance for 5 days, instead of 7 days in 2016. Actually, in terms of the formation of the financial reserves, the social insurance funds united into one Fund are more acceptable.

The dynamics of indicators of the financial reserves of the state pension social insurance is presented in Table 5 .

\section{Table 5}

The indicators of financial reserves of the state social pension insurance

\begin{tabular}{|c|c|c|c|}
\hline Indicators & 2014 & 2015 & 2016 \\
\hline Prv, thousand UAH & - & - & - \\
\hline Crv, thousand UAH & 2098,1 & 1720,7 & 840,6 \\
\hline $\begin{array}{l}\text { The total financial reserves, } \\
\text { thousand UAH }\end{array}$ & 2098,1 & 1720,7 & 840,6 \\
\hline $\begin{array}{l}\text { The total expenditures of the } \\
\text { Pension Fund of Ukraine, } \\
\text { thousand UAH }\end{array}$ & 248945,1 & 267346,5 & 254066 \\
\hline $\begin{array}{l}\text { Specific weight of Prv in the } \\
\text { Pension Fund of Ukraine, } \%\end{array}$ & - & - & - \\
\hline $\begin{array}{l}\text { Specific weight of Crv in } \\
\text { the total expenditures of the } \\
\text { Pension Fund of Ukraine, \% }\end{array}$ & $\begin{array}{l}0,84 \\
*(0)\end{array}$ & $\begin{array}{l}0,64 \\
*(0)\end{array}$ & $\begin{array}{l}0,33 \\
*(0)\end{array}$ \\
\hline $\begin{array}{l}\text { Specific weight of the total } \\
\text { financial reserves in the } \\
\text { Pension Fund of Ukraine, \% }\end{array}$ & $\begin{array}{l}0,84 \\
*(0)\end{array}$ & $\begin{array}{l}0,64 \\
*(0)\end{array}$ & $\begin{array}{l}0,33 \\
*(0)\end{array}$ \\
\hline Prv, day & - & - & - \\
\hline Crv, day & 3 & 2 & 1 \\
\hline
\end{tabular}

Listed in Table 5 data about the financial reserves of the state pension insurance indicate:

A) The indicator Crv in 2016 has decreased by in three times as compared to 2014;

B) In 2014-2016, the balances of the cash of the Pension Fund of Ukraine was formed at the end of the reporting year in the amount of 2.981 million UAH, 1.7207 million $\mathrm{UAH}$, and 0.8406 million $\mathrm{UAH}$, which is nearly $0.5 \%$ of the Fund's total expenditures. The excess of the expenditures over on the income of the Pension Fund of Ukraine was observed. In fact, this indicates that there are no reserves for this kind of the state social insurance. Thus, the real balance of the cash at the end of the reporting year was $0 \%$. It is $0 \%$ that is the real value of the Crv in 2014-2016;

C) Absence of perspective reserves in 2014-2016.

As other types of the state social insurance, the decrease of the financial reserves in 2015-2016 is due to the beginning of hostilities in Ukraine. The indicator Crv for the state pension insurance, expressed in days, showed a deviation of its volume from the norm. This is especially noticeable in 2016, when it provided funding for this type of the state social insurance for 1 day, instead of 7 days. By doing so, it reached its critical minimum level.

Also, the absence of Prv in 2014-2015 demonstrates the absence of long-term state policy in the development of the state pension insurance in Ukraine.

In Tab. 6, we have represented the volume of the financial reserves for each of their types in the context of certain types of the state social insurance (in days).

\section{Table 6}

The indicators of financial reserves of certain types of state social insurance

\begin{tabular}{|l|c|c|c|}
\hline \multicolumn{1}{|c|}{ Indicators, days } & 2014 & 2015 & 2016 \\
\hline $\begin{array}{l}\text { Prv for the Compulsory State Social } \\
\text { Insurance Fund of Ukraine for } \\
\text { Unemployment }\end{array}$ & - & - & - \\
\hline $\begin{array}{l}\text { Crv for the Compulsory State Social } \\
\text { Insurance Fund of Ukraine for } \\
\text { Unemployment }\end{array}$ & - & 4 & 4 \\
\hline $\begin{array}{l}\text { Prv for the State Social Insurance } \\
\text { Fund for Temporary Incapacity }\end{array}$ & - & - & no data \\
\hline $\begin{array}{l}\text { Crv for the State Social Insurance } \\
\text { Fund for Temporary Incapacity }\end{array}$ & 22 & 11 & no data \\
\hline $\begin{array}{l}\text { Prv for the State Social Insurance } \\
\text { Fund against Accidents at Work and } \\
\text { Occupational Diseases }\end{array}$ & - & - & no data \\
\hline $\begin{array}{l}\text { Crv for the State Social Insurance } \\
\text { Fund against Accidents at Work and } \\
\text { Occupational Diseases }\end{array}$ & 3 & 1 & no data \\
\hline $\begin{array}{l}\text { Prv for the State Social Insurance } \\
\text { Fund }\end{array}$ & no data & no data & - \\
\hline $\begin{array}{l}\text { Crv for the State Social Insurance } \\
\text { Fund }\end{array}$ & no data & no data & 5 \\
\hline Prv for the Pension Fund of Ukraine & - & - & - \\
\hline Crv for the Pension Fund of Ukraine & 3 & 2 & 1 \\
\hline
\end{tabular}

Listed in Table 6 data about the financial reserves of all types of the state social insurance in 2014-2016 indicate:

A) Absence of perspective reserves of all types of the state social insurance in Ukraine;

B) The largest volumes of Crv were observed for the state social insurance for temporary incapacity;

C) The indicator Crv in 2016 has decreased by in some times as compared to 2014 for all types of the state social insurance in Ukraine;

Also, the data in Table 6 testify to the lack of uniform methodological requirements for the formation of financial reserves in Ukraine. Reductions in the financial reserves of the state social insurance funds over the past 3 years indicate deterioration in the sustainability of the entire system of the state social insurance in Ukraine.

\section{Conclusions}

Data in Tables indicate a lack of common methodological principles for the formation of the financial reserves of the state social insurance, which 
is confirmed by their various volumes, the absence of compulsory creation of them. The results over three years demonstrate that the step that will balance the financial resources of the state social insurance is the need to introduce unified requirements for the formation of the financial reserves of the state social funds.

Analysing the foregoing, one can conclude extrapolating the provisions of Article 14-3 of the Budget Code of Ukraine, we propose that the amount of the Crv should not exceed $2 \%$ of the budget expenditures of the state social funds, that is, to provide a seven-day need for financing insurance payments. At the same time, keeping the amount of cash at the end of the period (year) should become mandatory.

The proposed measures will enable the system of the funds of compulsory state social insurance in Ukraine to acquire a more manageable and clear construction, the study of which we see as prospects for the further research in this sphere.

\section{References:}

Zlepko, N.P., Kramarchuk S. P. (2007). Finansy. - Ternopil, TNEU, 114 p.

Vasylyk, O. D. (2000). Teoriya finansiv - Kyiv, NIOS, 416 p.

Verkhovna Rada of Ukraine. Budget Code of Ukraine. Retrieved from: http://zakon3.rada.gov.ua/laws/ show/2456-17/page2

Cabinet of Ministers of Ukraine. Postanova Cabinet of Ministers of Ukraine "Pro zatverdzhennya byudzhetu Fondu zagalnoobovyazkovogo derzhavnogo socialnogo straxuvannya na vypadok bezrobittya na 2016 rik". Retrieved from: http://zakon2.rada.gov.ua/laws/show/414-2016-\%D0\%BF

Cabinet of Ministers of Ukraine. Postanova Cabinet of Ministers of Ukraine "Pro zatverdzhennya byudzhetu Fondu zagalnoobovyazkovogo derzhavnogo socialnogo straxuvannya na vypadok bezrobittya na 2016 rik". Retrieved from: http://zakon3.rada.gov.ua/laws/show/226-2015-\%D0\%BF

The Compulsory State Social Insurance Fund of Ukraine for Unemployment. Board resolution. Retrieved from: http://www.dcz.gov.ua/doccatalog/document?id=383939

The State Social Insurance Fund of Ukraine for Temporary Incapacity. The information about the execution of the budget 2015. Retrieved from: http://www.fse.gov.ua/fse/control/main/uk/publish/article/936560

The State Social Insurance Fund of Ukraine for Temporary Incapacity. Board resolution. Retrieved from: http://www.fse.gov.ua/fse/control/odd/uk/publish/article/924982

Cabinet of Ministers of Ukraine. Postanova Cabinet of Ministers of Ukraine "Pro zatverdzhennya byudzhetu Fondu socialnogo straxuvannya Ukrayiny na 2016 rik”. Retrieved from: http://zakon3.rada.gov.ua/laws/show/532-2016$\% \mathrm{D} 0 \% \mathrm{BF}$

The State Social Insurance Fund of Ukraine Against Accidents at work and Occupational Diseases. Board resolution. Retrieved from: http://consultant.parus.ua/?doc=08X207D4B2

The State Social Insurance Fund of Ukraine Against Accidents at work and Occupational Diseases. Insurance Activity Report. Retrieved from: http://www.social.org.ua/view/5588

Cabinet of Ministers of Ukraine. Postanova Cabinet of Ministers of Ukraine "Pro zatverdzhennya byudzhetu Pensijnogo fondu Ukrayiny na 2014 rik”. Retrieved from: http://zakon3.rada.gov.ua/laws/show/202-2014$\% \mathrm{D} 0 \% \mathrm{BF}$

Cabinet of Ministers of Ukraine. Postanova Cabinet of Ministers of Ukraine "Pro zatverdzhennya byudzhetu Pensijnogo fondu Ukrayiny na 2015 rik”. Retrieved from: http://zakon3.rada.gov.ua/laws/show/67-2015$\% \mathrm{D} 0 \% \mathrm{BF}$

Cabinet of Ministers of Ukraine. Postanova Cabinet of Ministers of Ukraine "Pro zatverdzhennya byudzhetu Pensijnogo fondu Ukrayiny na 2016 rik”. Retrieved from: http://zakon3.rada.gov.ua/laws/show/190-2016$\% \mathrm{D} 0 \% \mathrm{BF}$

\section{Анатолий СИДОРЧУК}

\section{АНАЛИЗ ФИНАНСОВЫХ РЕЗЕРВОВ ГОСУДАРСТВЕННОГО СОЦИАЛЬНОГО СТРАХОВАНИЯ}

Аннотация. Целью работы является исследование практики создания финансовых резервов государственного социального страхования в Украине и определения их оптимального размера. В статье рассматривается сущность финансовых резервов государственного социального страхования, проводится их классификация и анализируется практика формирования в Украине. Финансовые резервы социального страхования определяются нами как часть общегосударственных финансовых резервов, основным своим назначением должны обеспечить устойчивость системы государственного социального страхования. Поиск ответа на вопрос выполняют данные резервы свое предназначение в Украине определяет актуальность темы исследования. Практика функционирования государственных целевых фондов свидетельствует о создании финансовых резервов в двух формах: оборотной кассовой наличности и остатка средств на начало бюджетного периода. Исходя из действующей практики, финансовые резервы 
государственного социального страхования в Украине рассматриваются нами как текущие (текущий резерв наличности) и перспективные (остатокденежныхсредств в началебюджетного периода). Методисследования позволяет определить, обеспечивают ли финансовые резервы устойчивость государственного социального страхования в течение трех лет $(2014,2015,2016)$. Методика. Результаты исследования были получены после анализа показателей бюджета фондов государственного социального страхования в Украине (2014, $2015,2016)$. В ходе исследований был использован анализ, синтез как методы теоретического исследования явлений. Сравнение и измерение используются в качестве эмпирических методов для проводимых исследований. Результат. Результаты исследования показали отсутствие единых методологических принципов формирования финансовых резервов государственного социального страхования в Украине, что подтверждается их разным объемом и отсутствием обязательного условия их создания. Кроме того, анализ показал отсутствие формирование перспективных финансовых резервов по всем видам государственного социального страхования в Украине. Экстраполируя положения статьи 14-3 Бюджетного кодекса Украины, мы предлагаем, чтобы остатки средств на конец отчетного периода составляли $2 \%$ от бюджетных расходов государственных социальных фондов, то есть обеспечивали семидневную потребность в финансировании страховых выплат. В то же время обязательным условием является сохранение суммы наличных денег в конце периода (года). Практическое значение. Для проведения исследований и обоснования соответствующих выводов были проанализированы показатели бюджетов фондов государственного социального страхования Украины за три года $(2014,2015,2016)$. Значение/оригинальность. Шагом, который уравновесит финансовые ресурсы государственного социального страхования, является необходимость введения единых требований к формированию финансовых резервов фондов государственного социального страхования. Предлагаемые меры позволят системе фондов обязательного государственного социального страхования в Украине приобрести более управляемое и четкое строительство, изучение которых мы рассматриваем как перспективу дальнейших исследований в этой сфере. 